\title{
Pelatihan Perilaku 3R; Right, Reality, Responsible pada Anak Buruh Migran di Kecamatan Donomulyo Kabupaten Malang
}

\author{
${ }^{1 *}$ Muslihati, ${ }^{2}$ Yuliati Hotifah, ${ }^{3}$ Ella Faridati Zen \\ Universitas Negeri Malang; Jalan Semarang 5 Malang \\ *Corresponding author: muslihati.fip@um.ac.id
}

\begin{abstract}
Abstrak
Kegiatan pengabdian ini bertujuan mengembangkan perilaku positif $3 R$ (right, reality, and responsible) pada anak buruh migran di kecamatan Donomulyo Malang. Wilayah sasaran meliputi desa Mentaraman, Kedung Salam, dan Purwodadi karena memiliki populasi anak buruh migran yang cukup besar. Melalui kajian awal pada Forum Peduli Anak Kecamatan Donomulyo diketahui bahwa permasalahan mitra adalah anak-anak buruh migran cenderung berperilaku negatif, diantaranya suka pergi tanpa pamit, lalai belajar dan ibadah karena bermain, bolos sekolah, dan kurang hormat pada orang tua. Dengan kecenderungan tersebut diasumsikan anak-anak buruh migran perlu dibantu mengembangkan perilaku positif. Untuk itu diperlukan upaya edukasi pengembangan perilaku yang baik dan benar, perilaku realistis dan perilaku bertanggungjawab bagi anak buruh migran. Materi kegiatan meliputi (1) pemahaman diri (2) hakikat perilaku $3 R$ (2) penyusunan rencana diri. Pelatihan dikemas dalam bimbingan kelompok dengan metode PIJAR yaitu Pahami diri, Identifikasi kebutuhan dan harapan, Jelaskan dan evaluasi perilaku saat ini, Arahkan rencana dan solusi dan Realisasi rencana
\end{abstract}

Kata kunci-anak buruh migran, forum peduli anak, perilaku 3R, Metode Pijar.

\begin{abstract}
This service activity aims to develop positive behaviors of $3 R$ (right, reality, and responsible) for the children of migrant workers in Donomulyo district, Malang. The target areas include the villages of Mentaraman, Kedung Salam, and Purwodadi because they have a large population of migrant workers' children. Through preliminary studies in the Donomulyo District Children's Care Forum it was found that the problem of partners was that migrant workers' children tended to behave negatively, including leaving without saying goodbye, neglecting to study and worship because of playing, skipping school, and lacking respect for parents. With this tendency, it is assumed that children of migrant workers need to be helped to develop positive behavior. For this reason, education efforts to develop good and right behavior, realistic behavior and responsible behavior for migrant workers' children are needed. Material activities include (1) self-understanding (2) the nature of behavior $3 R$ (2) preparation of self-plans. The training is packaged in group guidance with the PIJAR method namely SelfUnderstanding, Identification of needs and expectations, Explain and evaluate current behavior, Navigate plans and solutions and Realize plans.
\end{abstract}

Keywords - child migrant worker, child care forum, 3R behavior, PIJAR Method

\section{PENDAHULUAN}

K abupaten Malang, khususnya area Jalur Lintas Selatan (JLS) adalah kawasan pengirim buruh migran. Salah satu kecamatan yang menjadi daerah asal buruh migran adalah kecamatan Donomulyo. Daerah ini banyak mengirim buruh migran ke negara Hongkong, Taiwan, Korea, dan negara-negara Arab. Buruh migran perempuan mendominasi populasi warga desa yang memutuskan untuk meninggalkan kampung halamannya. Menurut penuturan tokoh masyarakat Donomulyo, niatan utama menjadi buruh migran tentulah dikarenakan motif ekonomi. Kemiskinan menjadi salah satu alasan utama mengapa mereka memilih menjadi buruh migran (Utami \& Sukamdi, 2012). Mereka rela berpisah keluarga, bahkan anak dan suami demi meraih masa depan yang lebih baik. Mereka berharap, beberapa tahun kemudian mereka akan dapat memperbaiki ekonomi keluarga dan memiliki hidup yang lebih layak dari aspek ekonomi. Harapan ini lebih kuat dibandingkan dengan keinginan untuk membesarkan anak dan mendampingi suami. 
Buruh migran sering disebut sebagai pahlawan devisa. Mereka menyumbang dana yang sangat banyak pada negara. Dalam satu setahun, trilyunan dana masuk ke Indonesia hidup ini memunculkan berbagai belahan dunia. Namun demikian, kehidupan buruh migran yang seolah-olah gemerlap dan menyenangkan, ternyata tidak seindah yang dibayangkan. Banyak persoalan yang muncul dari kehidupan buruh migran, diantaranyanya permasalahan pada keluarga yang ditinggalkan, termasuk anak-anak yang mereka tinggalkan (Wubbolding, 2005)

Pengiriman pekerja migran atau buruh migran memang memberikan dampak ekonomi bagi mereka, namun tidak banyak orang yang berpikir bahwa kondisi ini juga membawa dampak sosial terkait dengan keluarga dan anak-anak yang ditinggalkan Dalam pembahasan terkait masalah pekerja migran, biasanya proporsi terbesar yang dibicarakan lebih banyak pada aspek ekonominya saja, antara lain bagaimana para buruh migran dapat memanfaatkan hasil remitansi yang diperolehnya untuk sesuatu yang produktif, fasilitasi pelatihan yang dibutuhkan serta bantuan permodalan untuk membangun usaha di kalangan keluarga buruh migran (Suyanto, 2018; Nia \& Sari, 2017). Tetapi sedikit sekali pembahasan tentang bagaimana nasib anak-anak buruh migran yang ditinggalkan, apakah mereka tetap memperoleh hak-haknya, apakah mereka masih bersekolah, apakah mereka tetap mendapatkan kasih sayang yang dibutuhkan, apa yang harus dilakukan. Bila mereka rindu pada orang tuanya dan bagaimana mereka harus mengatasi rasa rindunya.

Hasil survei yang dilakukan Kementerian Pemberdayaan Perempuan dan Perlindungan terhadap buruh migran di luar negeri maupun yang akan berangkat bekerja ke luar negeri, ternyata sebagian besar dari mereka belum memahami hak anak. Mereka pergi untuk jarak yang jauh dan dalam jangka waktu yang lama, tanpa memperhatikan kesiapan anak yang ditinggalkan. Mereka menganggap bahwa anak-anak tidak perlu tahu berapa lama akan ditinggal dan mengapa harus ditinggal. Seolah anak-anak tidak punya hak untuk didengar pendapatnya. Kondisi inilah yang kemungkinan menyebabkan banyak anak-anak buruh migran berperilaku berbeda (negatif) dibandingkan denga anak-anak lainnya (Ardhanariswari dkk., 2012; Rosdianty, 2015).

Meskipun belum ada data yang pasti berapa jumlah anak-anak buruh migran yang ditinggalkan, tetapi karena dari sembilan juta buruh migran Indonesia sebagian telah berstatus pernah kawin, maka dapat diperkirakan bahwa jumlah anak-anak buruh migran yang ditinggalkan cukup besar, maka dapat dibayangkan bagaimana dampak pengiriman buruh migran terhadap tumbuh kembang anak-anak tersebut. Kondisi inilah yang harus mendapat perhatian serius dari semua pihak.

Beberapa persoalan yang teridentifikasi dari focus group discussion dengan forum peduli anak kecataman Donomulyo diketahui bahwa dalam hal buruh migran pada tanggal 18 Januari 2018, terdapat berbagai masalah sebagai dampak pengiring. Dari aspek keluarga, cukup banyak buruh migran yang baru saja memiliki anak namun terpaksa harus berangkat ke negara sasaran. Buruh migran ini rela meninggalkan suami dan anak demi uang. Sementara itu sang anak diasuh oleh nenek atau kerabat lainnya. Masalah mulai muncul ketika seiring dengan usia anak, muncul perilaku anak yang sulit diarahkan, sangat manja, cuek pada sekitar, suka berkelompok dan kemudian pergi tanpa tujuan, bolos sekolah dan terlibat hubungan seksual pranikah.

Karena itu maka kegiatan pengabdian ini dimaksudkan untuk melatih anak-anak buruh migran menganai perilaku $3 \mathrm{R}$ yaitu perilaku yang right atau benar secara agama, norma dan budaya, perilaku yang realistis atau perilaku saat ini yang sesuai kondisi diri, dna ketiga perilaku responsible atau perilaku bertanggungjawab. Ketiga perilaku tersebut akan dapat mengembangkan pribadi positif pada anak buruh migran.

Kegiatan ini bertujuan membantu mitra mengatasi permasalahan yaitu: (1) anak buruh migran cenderung berperilaku kurang positif dan memerlukan pelatihan pengembangan perilaku bertanggung jawab. (2) anak buruh migran kurang memiliki pehamanan diri yang baik, (3) anak buruh migran kurang mengetahui perilaku yang mendukung cita-cita dan harapannya, serong mengalami kesulitan dalam berperilaku positif, dan tidak memiliki rencana nyata. (4) anak buruh migran cenderung kurang asertif dalam mengantisipasi ajakan teman untuk berperilaku negatif. Dengan permasalahan tersebut maka target perubahan yang diharapkan adalah setelah mengikuti kegiatan ini, peserta yaitu anak buruh migran ditargetkan untuk mampu (1) memahami diri dan lingkungannya (2) memahami perilaku yang baik dan benar, realistis dan bertanggungjawab (3) mengembangkan rencana diri (4) melakukan latihan pengembangan rencana diri untuk berperilaku positif.

\section{METODE}

Kegiatan ini menerapkan metode Pijar yaitu Pahami diri, Identifikasi kebutuhan dan harapan, Jelaskan dan evaluasi perilaku saat ini, Arahkan 
rencana dan solusi dan Realisasi rencana. Metode ini merupakan rangkaian tahap kegiatan yang terdiri dari Pahami diri, Identifikasi kebutuhan dan harapan, Jelaskan dan evaluasi perilaku saat ini, Arahkan rencana dan solusi dan Realisasi rencana. Model ini dikembangkan dari konsep dasar Choice Theory and Reality Therapy. Terapi ini berfokus pada pengembangan perilaku positif dan pengembangan penggung jawab. (Wubbolding, 2011; Burdenski \& Wubbolding, 2011). Teori ini dipilih karena sesuai dengan permasalahan anak-anak buruh migran di lokasi sasaran pengabdian masyarakat. Pendekatan ini akan dimodifikasi sesuai dengan karakteristik anak-anak. Karena itu maka teknik-teknik yang digunakan akan disesuaikan dengan perkembangan anak. salah satu nya melalui menggambar dalam mengungkapkan kondisi diri anak (Davis, 2011).

Dalam realisasinya akan dilakukan kegiatankegiatan penerapan tahapan Model Pijak dengan melakukan bimbingan dan pembelajaran aktif melalui metode ekspositori persuasif, metode dialog interaktif, metode diskusi kelompok, dan metode permainan dan penugasan. setelah pelaksanaan pelatihan akan dilakukan pendampingan dan konsultasi. Pendampingan dan konsultasi akan dilakukan melalui sosial media Whatsapp. Selanjutnya akan dilakukan evaluasi dan refleksi kegiatan. Agar kegiatan ini tetap berkelanjutan akan dilakukan follow up.

Pada tahap awal dilakukan perencanaan melalui analisis situasi dan penentuan prioritas masalah yang telah ditulis dan digambarkan justifikasinya pada bagian tiga. Pada bagian ini diuraikan prosedur realisasi metode.

Metode kegiatan pengabdian kepada masyarakat ini direalisasikan melalui prosedur sebagai berikut.

1. Perencanaan Pelatihan dan Penentuan sasaran. Jumlah sasaran dan personil sasaran akan melibatkan LP3T2A melalui survey yang dibantu oleh forum peduli anak buruh migran Kecamatan Donomulyo. Pada tahap pertama ini adalah melakukan seleksi calon peserta pelatihan. Syaratsyarat tersebut meliputi; (1) usia calon peserta pelatihan berkisar antara $13 \mathrm{sd} 17$ tahun atau usia remaja (2) memiliki permasalahan yang disebutkan dalam permasalahan mitra.

2. Pengembangan bahan pelatihan oleh tim pelaksana.

Bahan pelatihan yang dikembangkan yaitu (1) buku panduan kegiatan, (2) buku materi (3) media pelatihan berupa power point dan sejumlah instrumen evaluasi proses dan hasil.

3. Implementasi Pelatihan Perilaku 3R (Right, Reality and Responsible)

Kegiatan melalui 2 kali kegiatan, yaitu kegiatan pelatihan awal (In), pelaksanaan rencana diri secara mendiri (On) dan ketiga presentasi hasil, refleksi kegiatan dan pelaporan. Pelatihan dilaksanakan dengan menggunakan salah satu pendekatan konseling yaitu konseling realita yang dimodifikasi menjadi model PIJAR sehingga sesuai dengan kondisi sasaran. Pelatihan dilakukan untuk melatih peserta agar memahami diri, mampu merencanakan masa depan dan menentukan perilaku positif $3 \mathrm{R}$ yang akan menunjang keberhasilannya. Pelatihan dilakukan selama 14 jam setara dengan 2 hari pelatihan dengan tiap hari rata-rata 7 jam. Materi pelatihan meliputi Pemahaman Potensi Diri, Resiko dan Bahaya Pergaulan, Perencanaan Pribadi, Akademik dan Karier, Perilaku Positif 3R, Keterampilan Pengambilan Keputusan. Seluruh materi tersebut dikompilasikan dalam modul pelatihan.

Kegiatan ini bermitra dengan LP3TP2A Kabupaten Malang dan juga melibatkan Forum Peduli Anak kelurahan Donomulyo. LP3TP2A membantu dalam hal penyiapan dan jejaring kelompok sasaran, fasilitasi penyediaan tempat pelatihan berupa sarana prasarana gedung kegiatan dan sarana pendukung lainnya. Dengan kerjasama tersebut maka kegiatan ini dilaksanakan di Panti Asuhan Hidayah Donomulyo.

Dalam proses pelatihan, peserta pelatihan dibagi menjadi beberapa kelompok yang terdiri dari empat sampai enam orang anggota. Pelatihan terdiri dari 6 sesi, dengan durasi satu setengah sampai dengan dua jam tiap sesinya. Dalam setiap sesi disajikan pula tugas-tugas latihan. Pertemuan diselenggarakan dalam kelompok besar sejumlah 37 orang anak buruh migran. Target capaian setelah pelatihan mencapai kurang lebih $75 \%$, masing-masing peserta pelatihan memperoleh tugas individual, dan menerapkan panduan berbagai aktivitas dan umpan baik yang diperoleh, mendiskusikan dengan peserta lainnya tentang apa yang telah mereka lakukan selama pelatihan, tipe dan level masalah yang bagaimana yang mereka tangani, tipe setting atau konteks dan kesiapan peserta dalam menjalankan tugas yang diberikan. Evaluasi kegiatan dilakukan melalui wawancara dan pengamatan.

\section{HASIL DAN PEMBAHASAN}

Pelaksanaan kegiatan ini hingga telah menghasilkan beberapa hal itu capaian target kegiatan berupa peningkatan pengetahuan peserta tentang hakikat perilaku $3 \mathrm{R}$ dan manfaatnya dalam kehidupan, kemampuan peserta dalam memahami potensi diri, kemampuan peserta dalam 
mengembangkan rencana perilaku yang baik. Ketercapaian target tersebut diketahui melalui paparan refleksi secara verbal yang dilakukan pada saat akhir kegiatan. Berdasarkan hasil refleksi peserta diakhir kegiatan, peserta memperoleh hasil yang baik berupa pemahaman diri dan keterampilan mengembangkan rencana aktivitas atau kegiatan secara bertanggung jawab.

Peningkatan kemampuan tersebut terlihat dari hasil kerja peserta ketika melakukan aktivitas pelatihan. Dalam proses kegiatan, menyampaikan persepsi diri, pemahaman diri dan kebiasaan seharihari. Selanjutnya pelatih memberikan pertanyaan umpan balik yang bertujuan mengajak peserta melakukan evaluasi diri dan refleksi apakah perilakunya sudah tepat ataukan belum. Peserta menuliskan pandangan, sikap dan rencananya dalam sebuah kertas secara berkelompok dan kemudian di presentasinya di hadapan forum kegiatan. Proses sedemikian untuk melatih keterbukaan diri dan komitmen berperilaku baik, realistis dan bertanggung jawab.

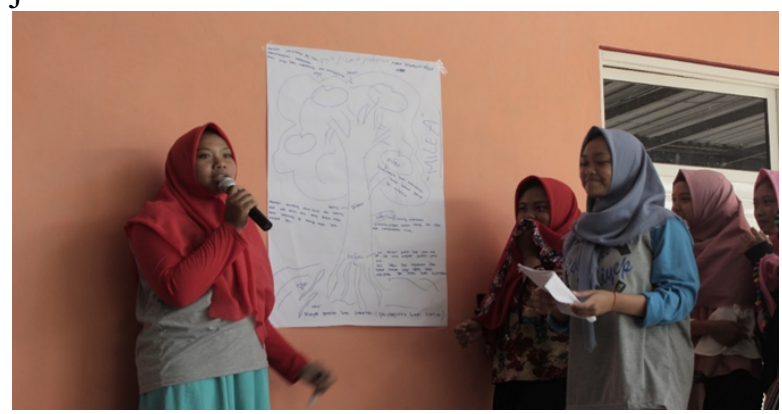

Gambar 1 ilustrasi kegiatan pemaparan

Gambar tersebut di atas merupakan illustrasi kegiatan pemaparan pandangan diri, kebiasaan diri dan evaluasi diri. Dalam latihan Pahami Diri, anakanak buruh migran di Donomulyo dilatih untuk mengidentifikasi dan menyadari potensi dirinya baik berupa potensi fisik dan psikologis. Mereka berlatih berani menuliskan ciri-ciri fisik, harapan dan keinginan, hobbi, kemampuan dan potensi diri yang dapat dikembangkan. Latihan ini menjadi menarik minat anak-anak karena ada unsur visualisasi dan melalui pembelajaran aktif dimana kegiatan dikemas dalam kegiatan "pohon potensi diriku". Setiap peserta dengan percaya diri memilih menjadi bagian dari pohon dengan berlandaskan pandangan dan nilai- nya sendiri mengenai diri mereka dan lingkungan sekitar. Latihan yang dilakukan secara berkelompok ini juga dirasakan peserta dapat melatih dia mengembangkan rasa percaya diri dan kemampuan bekerjasama. Penataan peserta dalam pengelompokan bertujuan menciptakan keakraban dan proses belajar kolaboratif.
Latihan Identifikasi Harapan dan Kebutuhan dilakukan melalui latihan indivual, dimana setiap peserta atau setiap anak buruh migran menuliskan harapannya dalam lembar kertas kerja dan menggambar Pohon Keluarga; telah membantu peserta dalam melakukan pengungkapan diri dan kondisi relasi sosial khususnya dalam keluarga.Sementara gambar dibawah adalah pelatihan perilaku realistik dalam mengembangan relasi positif dengan teman sebaya.

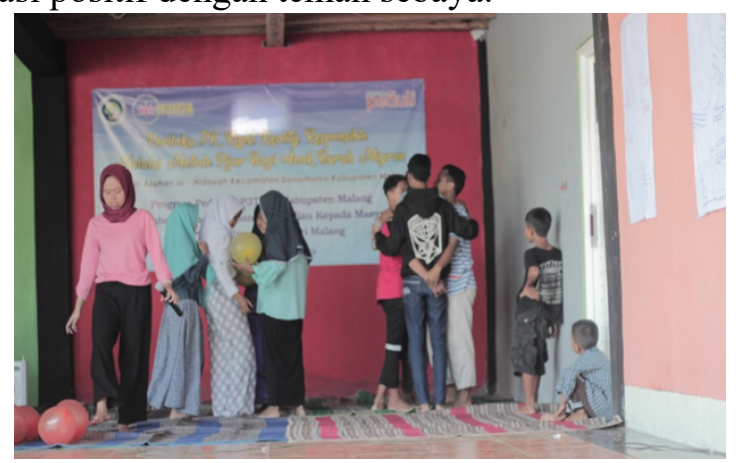

Gambar 2 Pelaksanaan Evaluasi Kegiatan

Pelaksanaan evaluasi kegiatan dilakukan secara langsung melalui penyampaian verbal. Setiap anak diajak untuk menyampaikan perasaan, pikiran dan komitmen dalam berperilaku baik, realistis dan bertanggung jawab. Aktivitas semacam ini dapat bertujuan membangun kepercayaan diri dan keberanian anak-anak untuk mengungkapkan keberadaan dirinya sekaligus melatih kemampuan berkomunikasi di hadapan forum.

Sebagai akhir dari kegiatan pelatihan ini anakanak buruh migran yang terlibat dalam kegiatan menuliskan rencana diri yang meliputi harapan masa depan atau rencana jangka panjang dan rencana jangka pendek. Mereka juga menulis upaya dan komitmen perilaku yang akan dilakukannya untuk untuk mencapai cita-cita tersebut. Komitmen perilaku dibawa pulang dan ditempel di dinding kamar anak buruh migran sebagai pengingat bahwa mereka adalah pribadi positif yang memiliki harapan besar dan cita-cita mulia dan ingin meraih masa depan yang cemerlang.

Kegiatan ini dilaksanakan berdasarkan panduan dan materi pelatihan karena yang sekaligus menjadi luaran kegiatan ini. Sementara proses pelatihan telaj direkam dalam bentuk video pelatihan yang diunggah ke media sosial You Tube dengan alamat tautan url https://youtu.be/QgAmDbfB7OE dengan Judul Pelatihan Perilaku 3R untuk Anak Buruh Migran Melalui Metode Pijar.

Kegiatan ini dilaksanakan sebagai salah satu upaya menjawab permasalahan sosial di kabupaten Malang khususnya di kecamatan Donomulyo yang 
merupakan wilayah kantong pengirim buruh migran. Pelaksanaan kegiatan ini dikhususkan pada sasaran anak buruh migran yang menerima dampak langsung dari kepergian ayah atau ibunya bekerja ke luar daerah asalnya.munculnya perilaku yang kurang bertanggung jawab seperti bolos, tidak disiplin dan bepergian jauh tanpa pamit menjadi gambaran bahwa anak-anak tersebut memerlukan bantuan.

Kegiatan pelatihan perilaku 3R melalui metode Pijar ini di maksudkan sebagai bantuan kepada anak buruh migran dalam mengembangkan perilaku bertanggung jawab dan siap menghadapi masa depannya. Harapan selanjutnya adalah, kegiatan ini dapat menginspirasi anak-anak buruh migran untuk tumbuh dalam cita-cita kemandirian dalam hal ekonomi dengan mengembangkan potensi daerah asalnya. Dengan demikian maka harapan berikutnya adalah memutus mata rantai pekerja migran tanpa keterampilan.

Metode yang diterapkan dalam pelaksanaan kegiatan ini yaitu Model Pijar dipandang memberikan inspirasi pada anak-anak buruh migran dalam memahami diri dan potensinya. Metode ini yang dilaksanakan dengan rangkaian kegiatan pelatihan dalam lima tahapan kegiatan ini mendapatkan sambutan antusias dari peserta. Peserta dengan aktif mengikuti setiap sesi dengan aktif. Mereka aktif dalam latihan memahami diri, mengindentifikasi kebutuhan dan harapan, menjelaskan dan mengevaluasi perilakunya saat ini dan mereka juga aktif dalam pengembangan rencana diri yang lebih baik sebagai upaya mengubah perilaku yang kurang baik.

Metode PIJAR dikembangkan dari teori choice sebuah teori berpijak pada pemikiran William Glasser. Teori ini dikenal juga dengan teori Terapi Realitas. Teori ini memandang manusia secara hakiki memiliki kebutuhan dasar dan selalu berusaha memenuhi kebutuhan tersebut. Kebutuhan dasar manusia meliputi kebutuhan bertahan hidup (survival), mencintai dan dicintai (love and belonging), meraih kekuasaan atau prestasi (power or achievement), meraih kebebasan atau kemerdekaan (freedom or independence), dan merasakan kesenangan (fun) (Corey, 2009). Diantara lima kebutuhan tersebut Glasser (1999) meyakini bahwa kebutuhan mencintai dan dicintai adalah kebutuhan paling utama dan paling sulit terpenuhi. Dengan pertimbangan teoritis tersebut maka proses kegiatan ini menekankan pada penanaman cara pandang pada anak buruh migran mengenai cara untuk mencintai diri sendiri dan sahabat secara tepat dan proporsional.

Penerapan teori Terapi Realitas dirumuskan oleh Wubbolding dalam langkah-langkah konseling yang disebut dengan langkah WDEP atau langkah want atau harapan, do atau perilaku, evaluation atau evaluasi diri dan planning atau rencana tindakan baru yang lebih positif. Tahapan tersebut bertujuan mengembangkan perilaku positif dan bertanggung jawab (Wubbolding, 2005; Burdenski \& Wubbolding, 2011). Dari rangkaian WDEP itulah kemudian tim pelatihan mengembangkan model PIJAR. Tahapan PIJAR merupakan modifikasi tahapan WDEP atau Want yang dikembang menjadi langkah pahami diri, identifikasi kebutuhan dan harapan,. Tahapan Do di jadikan satu dengan evaluasi, keduanya dikembangkan menjadi langkah jelaskan dan evaluasi perilaku saat ini sedengkan langkah $\mathrm{P}$ dikembangkan menjadi tahapan arahkan rencana dan solusi dan serta realisasi rencana.

Kegiatan pemahaman diri, identifikasi kebutuhan dan harapan, menjelaskan dan melakukan evaluasi diri serta menyusun rencana diri sangat sesuai dengan permasalahan anak-anak buruh migran di lokasi sasaran pengabdian masyarakat. Pendekatan ini juga telah dimodifikasi sesuai dengan karakteristik anak-anak melalui penggunaan media permainan simulasi, permainan karakter dan menonton film. Film yang dipilih juga berisikan pesan positif. Realisasi Metode PIJAR juga sesuai dengan tahap perkembangan anak yaitu pemaparan tujuan dan alur kegiatan melalui ekspositori dan kemudian diikuti dengan latihan-latihan lainnya. Semua latihan yang dilakukan secara berkelompok dipandang sesuai dengan karakteristik anak-anak sebagai individu yang sedang berapa pada masa berkelompok. Aktivitas semacam ini dirasakan peserta dapat mengembangkan kepercayaan diri dan kemampuan bekerjasama sehingga merkera terampil berkolaborasi. Semua latihan yang diterapkan dipandang berdampak positif pada kesejahteraan jiwanya. Model PIJAR telah mampu melatih anakanak buruh migran memahami perilaku nya selama ini dan berlatih melakukan evaluasi diri. Dengan demikian teknik-teknik yang digunakan disesuaikan dengan perkembangan anak, salah satu nya melalui menggambar dalam mengungkapkan kondisi diri anak (Davis, 2011).

\section{SIMPULAN}

Setelah realisasi pelaksanaan kegiatan pengabdian Pelatihan Perilaku 3R bagi anak buruh migran melalui metode Pijar diperoleh kesimpulan bahwa kegiatan ini telah berhasil memfasilitasi anakanak buruh dalam (1) memahami dirinya dan lingkungannya (2) memahami perilaku yang baik dan benar, realistis dan bertanggungjawab (3) mengembangkan rencana diri. Selanjutnya hasil kegiatan ini diharapkan tetap berhasil menumbuhkan 
perilaku disiplin dan bertanggung jawab pada anakanak dan remaja. Dari kegiatan ini selanjutnya diharapkan kepada (1) pemerintah agar terus mengembangkan program edukasi pada anak-anak buruh migran (2) pada relawan pendamping anak buruh migran dalam hal ini forum peduli anak yang dikoordinir oleh LP3P2TP2A agar dapat terus memantau perkembangan perilaku $3 \mathrm{R}$ anak buruh migran, supaya perilaku yang telah dilatihkan dapat terus dipelihara dan dikembangkan menjadi lebih baik (3) perusahaan swasta agar memiliki kepedulian pada anak buruh migran melalui program corporate social responsibility (CSR).

\section{DAFTAR RUJUKAN}

Burdenski, T., \& Wubbolding, R. (2011). Extending Reality Therapy with Focusing: A Humanistic Road for the Choice Theory Total Behavior Car. International Journal of Choice Theory and Reality Therapy, 31(1), 14-30.

Ardhanariswari, R., Handoko, W., \& Marwah, S. (2012). Pembentukan Model Perlindungan Anak Buruh Migran di Kabupaten Banyumas. Jurnal Dinamika Hukum, 12(1), 1-14.

Corey, G. (2009). Theory and Practice of Counseling and Psychotherapy, 8th Edition. Belmont, CA: Thomson Brooks.

Davis, E. S. (2011). Drawing out the child: Combining the WDEP method with drawing to work with children. International Journal of Choice Theory and Reality Therapy, 31(1), 4852.

Glasser, W. (1999). Choice Theory: A New Psychology of Personal Freedom. New York: Harper Perennial.

Nia, B., \& Sari, R. A. P. (2017). Tingkat Perubahan Kesejahteraan Ekonomi Keluarga Buruh Migran. INTAJ: Jurnal Penelitian Ilmiah, 1(1), 120-144.

Suyanto, S. (2018). Pemanfaatan Remitan Ekonomi dan Ketergantungan Migran Kembali Bekerja di Luar Negeri. Endogami, 2(1), 30-37.

Utami, R. T., \& Sukamdi, S. (2012). Pengambilan Keputusan Bermigrasi Pekerja Migran Perempuan (Kasus di Desa Jangkaran, Kecamatan Temon Kabupaten Kulon Progo). Jurnal Bumi Indonesia, 1(1), 1-10.

Wubbolding, R. E. (2005). The Power of Belonging. International Journal of Reality Therapy, 24(2), 43-44. 